\title{
ANALISIS FINANCIAL DISTRESS PADA PT TUNAS BARU LAMPUNG TBK DI BURSA EFEK INDONESIA
}

\author{
Umi Ambarwati \\ Sudarwati \\ Rochmi Widayanti \\ Fakultas Ekonomi Universitas Islam Batik Surakarta \\ e-mail: umiambarwati95@gmail.com
}

\begin{abstract}
This article aims to analyze the health of the company in PT Tunas Baru Lampung TBK in Indonesia Stock Exchange. The data comes from PT Tunas Baru Lampung TBK in 20132015. The methods used are Altman Z-Score, Springate, Zmijewski and Fulmer methods. The results of the study show that there are differences in predicted bankruptcy results between the Altman Z-score method, Springate, Zmijewski and Fulmer. This is due to differences in the use of financial ratios and criteria bankruptcy between Altman Z-score, Springate, Zmijewski and Fulmer. For that company is expected to increase sales, perform effective strategies, reduce operational costs to be more efesian so that companies can meet the company's health criteria.
\end{abstract}

Keywords: altman z-score, financial distres, fulmer, grover, springate, zmijewski

\begin{abstract}
ABSTRAK
Artikel ini bertujuan untuk menganalisis kesehatan perusahaan pada PT Tunas Baru Lampung TBK di Bursa Efek Indonesia. Data berasal dari PT Tunas Baru Lampung TBK pada tahun 2013-2015. Metode yang digunakan adalah metode Altman Z-Score, Springate, Zmijewski dan Fulmer. Hasil penelitian menunjukkan adanya perbedaan hasil prediksi kebangkrutan antara metode Altman Z-score, Springate, Zmijewski dan Fulmer. Hal ini karena adanya perbedaan penggunaan rasio keuangan dan kriteria kebangkrutan antara Altman Z-score, Springate, Zmijewski dan Fulmer. Untuk itu perusahaan diharapkan meningkatkan penjualan, melakukan strategi yang efektif, menekan biaya operasional agar lebih efesian sehingga perusahaan dapat memenuhi kriteria kesehatan perusahaan.
\end{abstract}

Kata kunci: altman z-score, financial distress springate, fulmer, grover , zmijewski

Meningkatnya mobilitas, kuantitas serta kualitas ilmu pengetahuan dan teknologi, mengakibatkan perubahan yang demikian cepat dalam kehidupan dunia usaha. Perubahan yang terus menerus ini berdampak pada kondisi perkembangan dunia usaha sangat pesat, banyak perusahaan baru mulai bermunculan, mulai dari perusahaan kecil sampai perusahaan besar. Setiap perusahaan tingkat penjualan menjadi salah satu nilai keberhasilan dari jenis usaha yang bersangkutan. Semakin tinggi tingkat penjualan suatu perusahaan, dengan asumsi besar keuntungan yang didapat sama besar, maka semakin tinggi tingkat laba yang dihasilkan. Salah satu indikator 
untuk melihat apakah perusahaan tersebut berkembang dengan baik atau tidak secara garis besar adalah dengan melihat banyaknya penjualan yang berhasil dilakukan oleh perusahaan.

Keadaan perekonomian yang tidak stabil membut perusahaan harus mampu mengelola sumber daya yang dimiliki secara efektif dan efesien. Salah satu penyebab perekonomian yang tidak stabil adalah karena kita memasuki era globalisasi dimana perusahaan bersaing tidak hanya dengan para pesaing lokal tetapi juga para pesaing dari luar negeri. Hal ini berdampak pada kemampuan perusahaan dalam mempertahankan bisnisnya (Rahmadini, 2016).

Suatu perusahaan go-public maupun belum public laporan keuangan merupakan hal yang penting untuk mengetahui tingkat keuntungan dan tingkat kerugian yang akan bermanfaat bagi investor atau stake holder perusahaan di masa yang akan datang (Peter dan Yoseph, 2011). Namun sering kali perusahaan mengalami kesulitan keuangan (financial distress) saat perusahaan tidak dapat memenuhi jadwal pembayaran atau ketika proyeksi arus kas mengindikasikan perusahaan tidak dapat memenuhi kewajibannya. Setiap perusahaan harus mewaspadai adanya potensi kebangkrutan, oleh karena itu perusahaan harus melakukan analisis yang menyangkut kebangkrutan perusahaan (Mastuti, dkk 2011).

Berbagai metode analisis dikembangkan untuk memprediksi awal kebangkrutan perusahaan. Menurut Peter dan Yoseph (2011) Springate menggunakan step-wise multiple discriminate analysis untuk memilih empat dari 19 rasio keuangan yang popular sehingga dapat membedakan perusahaan yang berada dalam zona bangkrut atau zona aman, sedangkan Zmijewski 1983 menambah validitas rasio keuangan sebagai alat deteksi kegagalan keuangan perusahaan. Zmijewski melakukan studi dengan menelaah ulang bidang studi kebangkrutan hasil riset sebelumnya selama dua puluh tahun. Metode Fulmer 1984 menggunakan metode step-wise multiple discriminate analysis untuk mengevaluasi 40 rasio keuangan yang diterapkan untuk sampel 60 perusahaan. Fulmer menemukan bahwa 30 perusahaan telah gagal dan sisanya 30 berhasil (Rajasekar et al, 2014). Metode Grover menggunakan sampel sesuai dengan model Altman Z-score pada tahun 1968, dengan menambahkan tiga belas rasio keuangan baru. Sampel yang digunakan sebanyak 70 perusahaan dengan 35 perusahaan yang bangkrut dan 35 perusahaan yang tidak bangkrut pada tahun 1982 sampai 1996 (Prihanthini dan Sari, 2013). Sementara itu menurut Altman (1968) dalam Rasidah dan Sarwani (2008) mengkombinasikan beberapa rasio keuangan menjadi suatu model prediksi dengan teknik statistik, yaitu analisis diskriminan yang dapat digunakan untuk memprediksi kebangkrutan perusahaan maka nilai Z-Score dapat menggambarkan posisi keuangan perusahaan dalam kondisi sehat, rawan atau kondisi bangkrut.

Salah satu aspek pentingnya analisis terhadap laporan keuangan sebuah perusahaan adalah kegunaannya untuk meramal kontinuitas atau kelangsungan hidup perusahaan. Prediksi kelangsungan hidup perusahaan sangat penting bagi manajemen dan pemilik perusahaan untuk mengantisipasi kemungkinan adanya potensi kebangkrutan (Widuri, 2012). Kesulitan keuangan diketahui untuk menganalisis data yang terdapat dalam laporan keuangan. Laporan keuangan yang diterbitkan oleh perusahaan merupakan salah satu sumber informasi mengenai posisi keuangan perusahaan, kinerja serta perubahan posisi keuangan perusahaan, yang sangat berguna untuk mendukung pengambilan keputusan yang tepat (Rasidah dan Sarwani, 2008).

PT Tunas Baru Lampung Tbk (TBLA) menjadi salah satu anggota dari Sungai Budi Group, salah satu perintis industri pertanian di Indonesia yang didirikan pada tahun 1947. TBLA berdiri karena keinginan mendukung pembangunan negara dan memanfaatkan keunggulan kompetitif Indonesia di bidang pertanian. PT Tunas Baru Lampung Tbk mulai beroperasi di Lampung pada awal tahun 1975, sejak itu kami telah berkembang menjadi salah satu produsen minyak goreng terbesar 
dan termurah. PT. Tunas Baru Lampung Tbk terdaftar di Bursa Efek Jakarta pada tanggal 14 Februari 2000. Tunas Baru Lampung (2016). Kelapa Sawit merupakan komoditas sub sektor perkebunan yang berperan penting dalam perekonomian Indonesia. Selain sebagai penyedia bahan baku dan penyerap tenaga kerja, kelapa sawit juga merupakan penghasil devisa negara terbesar setelah minyak dan gas (Istiarti, 2014).

Beberapa penelitian telah dilakukan untuk menguji manfaat rasio keuangan dalam menganalisis tingkat kesehatan keuangan perusahaan. Adapun penelitian mengenai manfaat rasio keuangan hasilnya menunjukkan bahwa rasio keuangan bermanfaat dalam menilai kondisi kesehatan keuangan untuk memprediksi kebangkrutan perusahaan (financial distress). Penelitian tentang TBLA ini belum banyak yang meneliti apakah perusahaan dalam kondisi bangkrut atau sehat.

Penelitian sebelumya oleh Juliana (2012) pada PT Tunas Baru Lampung tahun 2011 mengalami kondisi yang sehat dengan Metode Springate dan Metode Zmijewski sedangkan Metode Altman tahun 2011 mengalami grey area. Kalau pada tahun 2013 mengalami penurunan laba dan tahun 2011 mempunyai kondisi yang sehat dan berada dalam grey area. Maka peneliti akan meneliti pada tahun 2013-2015 apakah perusahaan dalam kondisi sehat atau bangkrut menurut Springate, Zmijewski, Fulmer, Grover dan Altman.

Perusahaan bisa bangkrut karena terjadi pertumbuhan ekonomi di China melambat sehingga mempengaruhi pertumbuhan ekonomi berbagai negara serta permintaan komoditas menurun. Dengan pertumbuhan ekonomi yang melemah, permintaan komoditas juga ikut melemah. Pasar minyak sawit di dunia juga dipengaruhi oleh banyak hal, seperti pasokan dan permintaan minyak nabati. Tunas Baru Lampung (2016). Berdasarkan uraian sebelumnya, maka artikel ini akan menganalisis Financial Distress menggunakan Metode Springate, Zmijewski, Fulmer, Grover dan Altman Z-Score pada PT Tunas Baru Lampung Tbk di Bursa Efek Indonesia Tahun 2013-2015".

Menurut Hanafi dan Halim (2014) menyatakan bahwa laporan keuangan perusahaan merupakan salah satu sumber informasi yang penting di samping informasi lain seperti informasi industri, kondisi perekonomian, dan lainnya. Sementara itu menurut Martono (2008) laporan keuangan (Financial Statement) merupakan ikhtisar mengenai keadaan keuangan suatu perusahaan pada suatu saat tertentu. Analisis laporan keuangan merupakan salah satu cara untuk mengetahui kinerja perusahaan dalam suatu periode (Kasmir).

Menurut Hanafi (2014) Kebangkrutan bisa dilihat dari pendekatan aliran dan pendekatan stok. Pendekatan stok, perusahaan bisa dinyatakan bangkrut jika total kewajiban melebihi total aktiva. Pendekatan aliran, perusahaan akan bangkrut jika tidak bisa menghasilkan aliran kas yang cukup. Sementara itu menurut Undang-Undang No. 4 Tahun 1998, kebangkrutan adalah keadaan dimana suatu institusi dinyatakan oleh keputusan pengadilan bila debitur memiliki dua atau lebih kreditur dan tidak membayar sedikitnya satu utang yang telah jatuh tempo dan dapat ditagih.

Menurut Hanafi (2014) indikator yang di pakai untuk memprediksi kebangkrutan yaitu indicator eksternal dan indicator internal. Indikator eksternal bisa diambil dari pasar keuangan dan informasi dari pihak yang berkaitan. Sebagai contoh, lembaga parenting memberi rating obligasi dari A sampai yang rating rendah $B$. Jika perusahaan mempunyai obligasi yang di rating jelek atau jika ratingnya diturunkan, maka kemungkinan kesulitan keuangan untuk perusahaan tersebut akan meningkat. Sementara indikator internal dapat diambil dari aliran kas perusahaan, strategi perusahaan dan laporan keuangan. Analisis ini ingin melihat kekuatan perusahaan relatif terhadap pesaingnya. Sebagai contoh, jika trend penjualan menunjukkan penurunan maka manajemen harus cepat melihat penyebabnya. Jika trend tersebut permanen dan dikarenakan perusahaan kehilangan 
daya saing, maka kemungkinan perusahaan akan mengalami kebangkrutan akan semakin besar. Informasi kebangkrutan merupakan suatu kabar penting tentang kegagalan keuangan termasuk melunasi kewajibannya dalam menjalankan aktivitas perusahaan yang dapat bermanfaat bagi pihak dalam atau luar perusahaan.

Subjek penelitian yang digunakan adalah PT Tunas Baru Lampung Tbk di Bursa Efek Indonesia Tahun 2013-2015 dengan objek laporan keuangan PT Tunas Baru Lampung Tbk di Bursa Efek Indonesia Tahun 2013-2015. Data yang digunakan dalam penelitian ini adalah data sekunder, yaitu data yang telah diolah dan tersedia dalam perusahaan. Metode yang digunakan adalah Altman Z-score, Springate, Zmijewski dan Fulmer

\section{Metode Springate}

Model ini dikembangkan pada tahun 1978 oleh Gorgon L.V. Springate. Dengan mengikuti prosedur yang dikembangkan Altman, Springate mengunakan step-wise multiple discriminate analysis untuk memiih empat dari 19 rasio keuangan yang popular sehingga dapat membedakan perusahaan yang berada dalam zona bangkrut atau zona aman (Peter dan Yoseph, 2011).

Menggunakan model Springate yang dikembangkan oleh Rajasekar, et al. (2014) mendiskripsikan dengan rumus sebagai berikut :

$S=1,03 A+3,07 B+0,66 C+0,4 D$

Dimana:

S : Indeks keseluruhan

A : Modal kerja terhadap total aktiva

B : Laba sebelum bunga dan pajak terhadap total aktiva

C : Laba sebelum pajak terhadap total kewajiban lancar

D : Penjualan terhadap total aktiva

Model tersebut mempunyai standar dimana perusahaan yang mempunyai skor $Z>0,862$ diklasifikasikan sebagai perusahaan sehat, sedangkan perusahaan yang mempunyai skor $Z<0,862$ diklasifikasikan sebagai perusahaan potensial bangkrut.

\section{Metode Zmijewski}

Zmijewski mengamati bahwa faktor eksternal seperti sektor industri, ukuran perusahaan dan siklus ekonomi adalah faktor penting yang mempengaruhi kebangkrutan kemungkinan. Oleh karena itu, ia menggunakan semua non-keuangan, non-layanan dan non-publik perusahaan administrasi yang terdaftar di Bursa Efek Amerika dan New York selama periode 1972 sampai 1978. Sampel estimasi studi Zmijewski terdapat 40 bangkrut dan 800 perusahaan non-bangkrut, dan sampel holdout terdiri dari 41 bangkrut dan 800 perusahaan non bangkrut. Model Zmijewski dirumuskan sebagai berikut (Kleinert, 2014):

$X=-4,3-4,5 X_{1}+5,7 X_{2}+0,004 X_{3}$

Dimana:

$X$ : Indeks keseluruhan

$X_{1}$ : Laba bersih terhadap total aktiva

$X_{2}$ : Total kewajiban terhadap total aset

$\mathrm{X}_{3}$ : Aset lancar terhadap kewajiban lancar 
Kriteria penilaian dengan hasil nilai $X$ yang negative maka perusahaan dalam kondisi sehat, sedangkan hasil nilai $X$ yang positif maka perusahaan mengalami kebangkrutan.

\section{Metode Fulmer}

Fulmer menggunakan metode step-wise multiple discriminate analysis untuk mengevaluasi 40 rasio keuangan yang diterapkan untuk sampel 60 perusahaan. Fulmer menemukan bahwa 30 perusahaan telah gagal dan sisanya 30 berhasil. Model Fulmer dapat dikembangkan oleh Rajasekar, et al (2014) mendiskripsikan dengan rumus sebagai berikut:

$\mathrm{H}=5,528(\mathrm{~V} 1)+0,212(\mathrm{~V} 2)+0,073(\mathrm{~V} 3)+1,270(\mathrm{~V} 4)-0,120(\mathrm{~V} 5)+2,335(\mathrm{~V} 6)+0,575(\mathrm{~V} 7)+$ $1,083(\mathrm{~V} 8)+0,894(\mathrm{~V} 9)-6,075$

Dimana:

$\mathrm{H} \quad$ : Indeks keseluruhan

V1 : Laba ditahan terhadap total aktiva

V2 : Penjualan terhadap total aktiva

V3 : Laba sebelum pajak terhadap total ekuitas

V4 : Arus kas terhadap total kewajiban

V5 : Total kewajiban terhadap total aset

V6 : Total kewajiban lancar terhadap total aktiva

V7 : Log total asset berwujud

V8 : Modal kerja terhadap total kewajiban

V9 : Log laba sebelum bunga dan pajak terhadap beban bunga

Kriteria penilaian dengan $\mathrm{H}<0$ maka perusahaan dalam kondisi bangkrut, sedangkan $\mathrm{H}>0$ maka perusahaan mengalami kondisi sehat.

\section{Metode Grover}

Menurut penelitian Prihantini (2013) Model Grover merupakan model yang diciptakan dengan melakukan pendesainan dan penilaian ulang terhadap model Altman Z-Score. Jeffrey S.Grover menggunakan sampel sesuai dengan model Altman Z-score pada tahun 1968, dengan menambahkan tiga belas rasio keuangan baru. Sampel yang digunakan sebanyak 70 perusahaan dengan 35 perusahaan yang bangkrut dan 35 perusahaan yang tidak bangkrut pada tahun 1982 sampai 1996. Grover (2001) menghasilkan fungsi sebagai berikut:

Score $=1,650 \mathrm{X}_{1}+3,404 \mathrm{X}_{3}-0,016 \mathrm{ROA}+0,057$

Dimana:

$X_{1}$ : Modal Kerja terhadap total aktiva

$\mathrm{X}_{3}$ : Pendapatan sebelum bunga dan pajak terhadap total aktiva

ROA: Laba bersih terhadap total aktiva

Model Grover mengkategorikan perusahaan dalam keadaan bangkrut dengan skor kurang atau sama dengan $-0,02(Z \leq-0,02)$. Sementara itu nilai untuk perusahaan yang dikategorikan dalam keadaan tidak bangkrut adalah lebih atau sama dengan $0,01(Z \geq 0,01)$.

\section{Metode Altman Z-Score}

Model kesulitan keuangan yang paling terkenal adalah Altman Z-Score menggunakan berbagai rasio untuk menciptakan alat prediksi kesulitan. Altman's Z-Score menggunakan teknik 
statistik (analisis diskriminan multiple-multiple discriminant analysis) untuk menghasilkan alat prediksi yang merupakan fungsi linier dari beberapa variabel penjelas. Alat prediksi ini menggolongkan atau memprediksi kemungkinan bangkrut atau tidak bangkrutnya perusahaan.

Penggunaan rasio sebagai alat prediksi kesulitan dapat digunakan untuk melengkapi analisis laporan keuangan yang melelahkan. Z-Score merupakan alat yang bermanfaat untuk menyaring, memantau, dan mengarahkan pada area tertentu (Wild dan Subramanyam, 2010: 288). sebagai berikut:

Menurut Altman (2000) untuk perusahaan manufaktur dapat dianalisis menggunakan rumus

$Z=0,717 x_{1}+0,847 x_{2}+3,107 x_{3}+0,420 x_{4}+0,998 x_{5}$

Dimana:

Z : Indeks Keseluruhan

$\mathrm{X}_{1}$ : Modal kerja terhadap total aktiva

$\mathrm{X}_{2}$ : Laba ditahan terhadap total aktiva

$X_{3}$ : Pendapatan sebelum pajak dan bunga terhadap total aktiva

$\mathrm{X}_{4}$ : Nilai pasar ekuitas terhadap nilai buku dari hutang

$X_{5}$ : Penjualan terhadap total aktiva

Kriteria perusahaan: Z > 2,90, maka termasuk perusahaan sehat, Z 1,23 - 2,90 maka termasuk perusahaan yang berada dalam daerah kelabu, $Z<1,23$ maka termasuk perusahaan bangkrut.

\section{HASIL DAN PEMBAHASAN Metode Springate}

Hasil perhitungan variabel pembentuk dan nilai Springate seperti tampak pada Tabel 1. Berdasarkan Tabel 1 hasil perhitungan variable dan nilai diatas menunjukkan bahwa PT Tunas Baru Lampung tahun 2013 dengan nilai 0,466, tahun 2014 nilai 0,844, dan tahun 2015 nilai 0,498 mengalami kebangkrutaan karena nilai di bawah 0,862 .

Tabel 1. Hasil Variabel dan nilai Springate Tahun 2013-2015

\begin{tabular}{ccccccc}
\hline Tahun & A & B & C & D & S-Score & Kriteria \\
\hline 2013 & 0,043 & 0,049 & 0,052 & 0,596 & 0,466 & Bangkrut \\
2014 & 0,036 & 0,104 & 0,217 & 0,864 & 0,844 & Bangkrut \\
2015 & 0,045 & 0,052 & 0,097 & 0,574 & 0,498 & Bangkrut \\
\hline
\end{tabular}

Sumber: data diolah

Variabel $\mathrm{A}$ (modal kerja terhadap total aktiva) mempunyai nilai yang menunjukkan kebangkrutan perusahaan karena modal kerja tidak sebanding dengan total aktiva. Walaupun pada tahun 2014 mengalami kenaikan pada investasi perusahaan di pabrikan dan tanaman kelapa sawit serta peningkatan dikarenakan penambahan fasilitas pinjaman Bank untuk membiayai kegiatan investasi perseroan. Pada variabel B (EBIT terhadap total aktiva) dimana EBIT berupa beban bunga dan laba sebelum pajak mengalami kenaikan tahun 2014 dan tahun 2015 menurun berbeda dengan total aktiva yang setiap tahun meningkat.

Variabel C (laba sebelum pajak terhadap total aktiva) menunjukkan nilai yang tidak bisa membuat perusahaan sehat karena laba sebelum pajak dan total aktiva tidak sebanding sehingga nilainya mengalami naik turun yang tidak bisa menetap ataupun naik terus untuk menuju kondisi 
perusahaan yang sehat. Pada variabel D (penjualan terhadap total aktiva) menunjukkan nilai yang tidak stabil. Tahun 2014 mengalami kenaikan secara signifikan sebesar $71 \%$ bila dibandingkan tahun 2013 sebesar $31 \%$ dan volume penjualan sebesar 30\% terutama penjualan gula dan minyak goreng. Kontribusi penjualan terbesar tahun 2014 berasal dari CPO sebesar 30\% dari total penjualan dan mengalami peningkatan sebesar $50 \%$ dari tahun 2013 , hal ini disebabkan peningkatan volume penjulan sebesar 35\%. Pada tahun 2015 nilai lebih kecil dari dua tahun sebelumnya karena menurunnya peningkatan harga jual rata-rata dan volume penjualan yang mengalami kenaikan signifikan adalah volume penjualan gula.

\section{Metode Zmijewski}

Hasil perhitungan variabel pembentuk dan nilai Zmijewski seperti tampak pada Tabel 2. Berdasarkan Tabel 2 hasil perhitungan variabel dan nilai diatas menunjukkan bahwa PT Tunas Baru Lampung tahun 2013 dengan nilai -0,3066, tahun 2014 dengan nilai -0,7816, dan tahun $2015-0,4674$ kondisi perusahaan sehat karena mempunyai hasil yang negative serta sesuai dengan kriteria perusahaan.

Tabel 2. Hasil Perhitungan Variabel dan nilai Zmijewski Tahun 2013-2015

\begin{tabular}{cccccc}
\hline Tahun & $\mathrm{X}_{1}$ & $\mathrm{X}_{2}$ & $\mathrm{X}_{3}$ & $\mathrm{X}$ Score & Kriteria \\
\hline 2013 & 0,013 & 0,710 & 1,120 & $-0,3066$ & Sehat \\
2014 & 0,059 & 0,663 & 1,104 & $-0,7816$ & Sehat \\
2015 & 0,021 & 0,689 & 1,155 & $-0,4674$ & Sehat \\
\hline
\end{tabular}

Sumber: data diolah

Variabel $\mathrm{X}_{1}$ (laba bersih terhadap total aktiva) menunjukkan nilai yang tidak stabil dari laba bersih walaupun tahun 2014 mengalami peningkatan dari tahun sebelumnya disebabkan oleh peningkatan harga jual rata-rata dan volume penjualan dari kenaikan gula sedangkan total aktiva yang setiap tahun meningkat terdiri dari kas, piutang usaha, pajak dibayar dimuka, persedian, dan lain-lain. Walaupun tidak stabil tetapi perusahaan mempunyai kondisi yang sehat.

Variabel $X_{2}$ (total kewajiban terhadap total aktiva) menunjukkan nilai yang baik karena pada saat total kewajiban naik berupa kewajiban lancar dan kewajiban tidak lancar maka total aktiva yang berupa aktiva lancar dan aktiva tidak lancar juga ikut naik. Pada tanggal 31 Desember 2015, kewajiban mengalami peningkatan sebesar 31\%. Hal ini disebabkan oleh peningkatan kewajiban jangka pendek sebesar $4 \%$ dan kewajiban jangka panjang sebesar $62 \%$. Total kewajiban naik disebabkan oleh peningkatan pinjaman bank, hutang usaha dan uang muka diterima pada akhir tahun 2015. Total aktiva yang terdiri dari aktiva lancar 33\% dan aktiva tidak lancar $67 \%$ ini mengalami kenaikan yang disebabkan oleh peningkatan investasi perusahaan di pabrikan dan tanaman kelapa sawit.

Variabel $\mathrm{X}_{3}$ (aktiva lancar terhadap hutang lancar) yang menunjukkan nilai baik sebanding antara aktiva lancar berupa piutang usaha dan persediaan dengan hutang lancar berupa utang bank jangka pendek. Walaupun tahun 2015 mengalami penurunan dari tahun sebelumnya perusahaan tetap sehat karena dengan adanya nilai $\mathrm{X}$ menurun maka akan berdampak baik bagi perusahaan.

\section{Metode Fulmer}

Hasil perhitungan variabel pembentuk dan nilai Fulmer seperti tampak pada Tabel 3. Berdasarkan Tabel 3 hasil perhitungan variabel dan nilai diatas menunjukkan bahwa PT Tunas Baru 
Lampung tahun 2013 dengan nilai 2,463 dengan kondisi yang sehat, tahun 2014 dengan nilai 0,673 juga mengalami kondisi yang sehat, dan tahun 2015 dengan nilai $-0,335$ perusahaan mengalami kondisi yang bangkrut.

Tabel 3. Hasil Perhitungan Variabel dan nilai Fulmer Tahun 2013-2015

\begin{tabular}{lccccccccccl}
\hline Tahun & V1 & V2 & V3 & V4 & V5 & V6 & V7 & V8 & V9 & H Score & Kriteria \\
\hline 2013 & 0,144 & 0,596 & 0,066 & 0,003 & 0,710 & 0,365 & 6,793 & 0,061 & 3,212 & 2,463 & Sehat \\
2014 & 0,173 & 0,864 & 0,228 & 0,108 & 0,663 & 0,353 & 6,865 & 0,055 & 0,789 & 0,673 & Sehat \\
2015 & 0,144 & 0,574 & 0,091 & 0,041 & 0,689 & 0,291 & 6,967 & 0,065 & 0,103 & $-0,335$ & Bangkrut \\
\hline
\end{tabular}

Sumber: data diolah

Variabel V1 (laba sebelum pajak terhadap total aktiva) mempunyai nilai yang tidak menetap karena nilainya setiap tahunnya naik turun dan tidak sebanding dengan total aktiva. Variabel V2 (penjualan terhadap total aktiva) mempunyai nilai yang tidak sama setiap tahunnya. Pada variabel V2 nilai yang paling tinggi pada tahun 2014 karena penjualannya naik dari tahun sebelumnya tetapi tahun 2015 mengalami penurunan yang lebih rendah dari tahun 2014 dan 2013 ini terjadi karena penurunan harga jual rata-rata produk perseroan sebesar $28 \%$ sedangkan dari segi volume penjualan mengalami peningkatan sebesar $17 \%$.

Variabel V3 (laba sebelum pajak terhadap total ekuitas) mempunyai nilai yang tidak stabil, nilai yang paling tinggi tahun 2014 terjadi karena laba sebelum pajak lebih kecil dari total ekuitas sedangkan tahun 2015 nilai ekuitas lebih besar dari laba sebelum pajak dan mengalami penurunan yang drastis serta nilai yang paling rendah tahun 2013. Variabel V4 (arus kas terhadap total kewajiban) mempunyai nilai yang tidak stabil. Arus kas ini terdiri dari penerimaan dari pelanggan, kas bersih dihasilkan dari operasi, pembayaran pajak ekspor, pembayaran beban bunga, pembayaran pajak penghasilan badan dII lebih kecil dari total kewajiban yang terdiri dari kewajiban jangka pendek seperti utang bank jangka pendek yang meningkat pada PT Bank OCBC NISP Tbk, PT Bank UOB Buana Tbk dan PT CIMB Niaga TBk dan kewajiban jangka panjang.

Variabel V5 (total kewajiban terhadap total ekuitas) mempunyai nilai yang setiap tahun tidak stabil terjadi karena naiknya kebutuhan perusahaan sehingga mengakibatkan nilai kewajiban naik seperti peningkatan pinjaman bank, hutang usaha dan uang muka diterima akhir tahun 2015. Variabel V6 (total kewajiban lancar terhadap total aktiva) mempunyai nilai yang naik pada tahun 2014 dan tahun 2015 mengalami penurunan. Total aktiva dapat memenuhi total kewajiban lancar yang terdiri dari utang bank, utang pajak, beban akrual serta utang usaha.

Variabel V7 (log total asset berwujud), ini mempunyai kenaikan setiap tahunnya yang terdiri dari asset lancar berupa kas, piutang usaha tahun 2015 mengalami kenaikan disebabkan adanya penjualan yang dilakukan menjelang akhir tahun sehingga seluruh piutang tersebut belum jatuh tempo dan manajemen yakin bahwa seluruh piutang dapat tertagih serta tidak diperlukan penyisihan atas penurunan nilai piutang usaha, pajak dibayar muka, persediaan mengalami peningkatan stok CPO di akhir tahun 2015 dan juga adanya peningkatan pupuk dan luasan tanaman tebu sedangkan asset tidak lancar berupa piutang pihak berelasi, asset pajak tangguhan, piutang plasma-bersih mengalami peningkatan disebabkan dana untuk pembangunan plasma tersebut masih dalam tahap pencarian oleh bank, serta asset tetap meningkat oleh pembangunan pabrik minyak goreng, pabrik biodesil juga adanya konstruksi perumahan dan infrastruktur baru yang mendukung proses produksi serta pabrik gula. Pada tahun 2015 aset mengalami peningkatan dari tahun sebelumnya, ini terjadi karena peningkatan investasi perusahaan di pabrikan dan tanaman kelapa sawit. 
Variabel V8 (modal kerja terhadap total kewajiban) mempunyai nilai yang tidak stabil karena modal kerja lebih kecil daripada total kewajiban atau total hutang maka dari itu perusahaan harus bisa memperkecil hutang usaha agar total kewajiban lebih kecil dari modal kerja. Tetapi pada tahun 2015 modal kerja mengalami kenaikan dikarenakan adanya penambahan fasilitas pinjaman Bank untuk membiayai kegiatan inovasi perseroan. Variabel V9 (log laba sebelum bunga dan pajak terhadap beban bunga) tahun 2013 mempunyai nilai yang tinggi tetapi tahun 2014 dan 2015 nilainya menurun drastis, ini terjadi karena laba sebelum bunga dan pajak lebih besar dari beban bunga.

\section{Metode Grover}

Hasil perhitungan variabel pembentuk dan nilai Grover seperti tampak pada Tabel 4.

Berdasarkan Tabel 4 hasil perhitungan variabel dan nilai di atas menunjukkan bahwa PT Tunas Baru Lampung tahun 2013 dengan nilai 0,294, tahun 2014 dengan nilai 0,469 dan tahun 2015 dengan nilai 0,307 perusahaan dalam kondisi yang sehat karena sesuai kriteria perusahaan yaitu lebih dari 0,01.

Tabel 4. Hasil Variabel dan nilai Grover Tahun 2013-2015

\begin{tabular}{cccccc}
\hline Tahun & $X_{1}$ & $X_{3}$ & ROA & $S$ & Kriteria \\
\hline 2013 & 0,043 & 0,049 & 0,013 & 0,013 & Sehat \\
2014 & 0,036 & 0,104 & 0,059 & 0,469 & Sehat \\
2015 & 0,045 & 0,052 & 0,021 & 0,307 & Sehat \\
\hline
\end{tabular}

Sumber: data diolah

Variabel $\mathrm{X}_{1}$ (modal kerja terhadap total aktiva), tahun 2013 modal kerja yang dihasilkan dari aktiva lancar dikurangi hutang lancar. Walaupun aktiva lancar dan hutang lancar tidak seimbang nilainya tetapi perusahaan masih dalam kondisi yang sehat. Tahun 2014 nilai $X_{1}$ lebih kecil dari taun sebelumnya dikarenakan modal kerja mengalami penurunan dan total aktiva mengalami kenaikan yang tinggi walaupun dengan kondisi yang seperti itu perusahaan masih dalam kondisi yang sehat. Tahun 2015 nilai $X_{1}$ mengalami kenaikan dari tahun sebelumnya baik modal kerja atau total aktiva dan perusahaan mengalami kondisi yang sehat.

Variabel $\mathrm{X}_{3}$ (EBIT terhadap total aktiva), tahun 2013 nilai EBIT lebih rendah dari tahun yang lainnya dan nilai EBIT ini tidak sebanding dengan total aktiva tetapi perusahaan masih dalam kondisi yang sehat. Tahun 2014 nilai EBIT mengalami kenaikan dari tahun sebelumya sedangkan total aktiva juga mengalami kenaikan walaupun tidak nilai tidak sebanding kondisi perusahaan masih dalam kondisi yang sehat. Tahun 2015 nilai EBIT mengalami penurunan dari tahun sebelumya karena pada saat nilai EBIT menurun dan total aktiva melambung tinggi kondisi perusahaan masih dalam sehat.

ROA (laba bersih terhadap total aktiva), tahun 2013 laba bersih mempunyai nilai lebih kecil dari total aktiva yang terdri dari aktiva lancar dan aktiva tidak lancar tetapi kondisi perusahaan masih dalam kondisi yang sehat. Tahun 2014 laba bersih mengalami kenaikan yang tinggi dari tahun sebelumnya sedangkan total aktiva juga mengalami kenaikan yang tinggi walaupun tidak seimbang antara laba bersih dan total aktiva kondisi perusahaan masih dalam kondisi yang sehat. Tahun 2015 nilai ROA lebih kecil dari tahun sebelumnya dikarenakan laba bersih yang menurun sedangkan total aktiva yang melambung tinggi tetapi kondisi perusahaan masih dalam kondisi yang sehat.

\section{Metode Altman Z-Score}

Hasil perhitungan variabel pembentuk dan nilai Z-Score seperti tampak pada Tabel 5. Berdasarkan Tabel 5 hasil perhitungan variabel dan nilai diatas menunjukkan bahwa PT Tunas Baru 
Lampung tahun 2013 dengan nilai 1,067 mengalami bangkrut, tahun 2014 nilai 1,568 mengalami grey area, sedangkan tahun 2015 dengan nilai 0,913 mengalami bangkrut dan untuk mencapai kriteria kesehatan di atas nilai 2,90.

Tabel 5. Hasil Variabel dan nilai Altman Z-Score Tahun 2013-2015

\begin{tabular}{cccccccl}
\hline Tahun & $X_{1}$ & $X_{2}$ & $X_{3}$ & $X_{4}$ & $X_{5}$ & $Z$ & Kriteria \\
\hline 2013 & 0,043 & 0,144 & 0,049 & 0,407 & 0,596 & 1,067 & Bangkrut \\
2014 & 0,036 & 0,173 & 0,104 & 0,506 & 0,864 & 1,568 & Grey Area \\
2015 & 0,045 & 0,144 & 0,052 & 0,449 & 0,574 & 0,913 & Bangkrut \\
\hline
\end{tabular}

Sumber: data diolah

Nilai Z yang mempunyai prediksi kebangkrutan. Pada variabel $X_{1}$ (modal kerja terhadap total aktiva), modal kerja yang terdiri dari aktiva lancar mengalami kenaikan terhadap piutang usaha disebabkan adanya penjualan dan persediaan pada volume gula, persediaan pupuk dan tanaman tebu sedangkan dari hutang lancar yang berupa piutang plasma mengalami peningkatan, tanaman perkebunan mengalami peningkatan luasan TBM serta kapitalisasi biaya perawatan ke dalam TBM dan asset tetap yang merupakan komponen terbesar kedua atas asset tidak lancar sehingga modal kerja lebih kecil dari total aktiva. Variabel $X_{1}$ setiap tahun nilainya tidak sama. Tahun 2014 nilai $X_{1}$ mengalami kenaikan dengan total aktiva lebih besar dari modal kerja tetapi perusahaan masih berada dalam grey area.

Variabel $\mathrm{X}_{2}$ (laba ditahan terhadap total aktiva) menunjukkan setiap tahun mengalami nilai yang tidak stabil untuk kebutuhan perusahaan yang lebih besar dengan total aktiva. Pada variabel $X_{3}$ (EBIT terhadap total aktiva) menunjukkan setiap tahun mempunyai nilai yang berbeda, EBIT dapat dilihat dari beban bunga yang berupa utang bank, obligasi, surat utang menengah, pinjaman diterima, liabilitas sewa pembayaran dan laba sebelum pajak dari perusahaan yang lebih besar dengan total aktiva.

Variabel $\mathrm{X}_{4}$ (nilai pasar ekuitas terhadap nilai buku hutang) menunjukkan setiap tahun mengalami nilai yang berbeda pada saham treasuri, saldo laba, kepentingan non pengendali yang lebih besar dari nilai buku hutang berupa kewajiban jangka pendek seperti utang usaha, utang pajak, beban akrual, utang bank jangka pendek terjadi karena peningkatan aktivitas pembelian barang dari pemasok dan kontraktor dimana perseroan membutuhkan pendanaan jangka pendek untuk menutupi modal kerja perseroan dan kewajiban jangka panjang seperti utang pihak berelasi, surat utang jangka menengah, utang obligasi, hutang bank jangka panjang dari PT Bank OCBC NISP Tbk dan PT Bank Permata TBk. Pada variabel $X_{5}$ (penjualan terhadap total aktiva) menunjukkan nilai penjualan lebih kecil dari total aktiva, penjualan dapat diperoleh dari pengolahan gula, tebu dan pengolahan kelapa sawit. Tahun 2014 mengalami kenaikan penjualan terhadap harga jual rata-rata dan volume penjualan terhadap gula dan minyak goreng tetapi tahun 2015 mengalami penurunan karena kurangnya daya beli masyarakat maka perusahaan harus membuat strategi untuk menaikkan nilai penjualan perusahaan.

\section{Perbandingan Metode Altman Z-Score, Springate dan Zmijewski}

Perbedaan antara model Altman Z-Score, Springate dan Zmijewski pada PT Tunas Baru Lampung Tbk Tahun 2013-2015 dapat dilihat pada Tabel 5. Tahun 2013 PT Tunas Baru Lampung mengalami kondisi yang bangkrut menurut Springate dengan hasil 0,466 di bawah 0,862, ini terjadi karena nilai $\mathrm{C}$ tidak sebanding dengan total kewajiban lancar sehingga tidak bisa memenuhi kriteria 
kesehatan sebuah perusahaan. Zmijewski perusahaan mengalami kondisi yang sehat karena hasilnya negatif dengan nilai -0,3066 walaupun ada variabel yang bernilai kecil. Fulmer perusahaan mengalami kondisi yang sehat karena mempunyai hasil lebih besar dari 0 walaupun variabel V4 lebih kecil dari variabel yang lain. Grover perusahaan mengalami kondisi yang sehat karena sesuai dengan kriteria perusahaan yaitu lebih dari 0,01 . Sedangkan menurut Altman perusahaan mengalami kondisi yang bangkrut dengan nilai 1,067 yang jauh dari kriteria nilai sehat perusahaan, ini terjadi karena nilai $X_{1}$ lebih kecil dibanding dengan nilai $X$ yang lain.

Tabel 5. Hasil Perbedaan Altman, Springate, Zmijewski dan Fulmer Tahun 2013-2015

\begin{tabular}{|c|c|c|c|c|c|c|c|c|c|c|}
\hline \multirow{2}{*}{ Tahun } & \multicolumn{2}{|c|}{ Springate } & \multicolumn{2}{|c|}{ Zmijewski } & \multicolumn{2}{|c|}{ Fulmer } & \multicolumn{2}{|c|}{ Grover } & \multicolumn{2}{|c|}{ Altman } \\
\hline & Nilai & Kriteria & Nilai & Kriteria & Nilai & Kriteria & Nilai & Kriteria & Nilai & Kriteria \\
\hline 2013 & 0,466 & Bangkrut & $-0,306$ & Sehat & 2,463 & Sehat & 0,294 & Sehat & 1,067 & Bangkrut \\
\hline 2014 & 0,844 & Bangkrut & $-0,781$ & Sehat & 0,673 & Sehat & 0,469 & Sehat & 1,568 & Grey Area \\
\hline 2015 & 0,498 & Bangkrut & $-0,467$ & Sehat & $-0,355$ & Bangkrut & 0,307 & Sehat & 0,913 & Bangkrut \\
\hline
\end{tabular}

Sumber: data diolah

Tahun 2014, PT Tunas Baru Lampung berada dalam kondisi bangkrut menurut Springate dengan hasil 0,844 ini juga mengalami kenaikan tetapi masih berada di bawah nilai sehat perusahaan. Kenaikan nilai pada Springate tidak hanya pada variabel $D$ tetapi juga pada variabel $B$ tentang EBIT terhadap total aktiva. Zmijewski berada dalam kondisi yang sehat dengan nilai $-0,7816$ ini mengalami kenaikan tetapi masih berada dalam kondisi sehat karena hasil negative. Fulmer perusahaan dalam kondisi yang sehat walaupun nilai $\mathrm{H}$ nya turun, itu terjadi karena variabel V7 mengalami kenaikan setiap tahunnya. Grover perusahaan mengalami kondisi yang sehat karena sesuai dengan kriteria perusahaan walaupun nilai mengalami kenaikan dari tahun sebelumnya. Sedangkan menurut Altman mengalami kondisi perusahaan yang berada dalam grey area dengan nilai 1,568 ini mengalami kenaikan dari tahun sebelumnya tetapi masih berada dalam grey area. Kenaikan itu berada dalam nilai $X_{5}$ pada penjualan terhadap total aktiva.

Pada tahun 2015 PT Tunas Baru Lampung berada dalam kondisi yang bangkrut menurut Springate dengan nilai 0,498 yang masih di bawah nilai sehat perusahaan. Penurunan dari variabel Springate yang paling kecil adalah variabel A yaitu modal kerja terhadap total aktiva sedangkan nilai yang paling besar ada pada variabel $D$ yaitu penjualan terhadap total aktiva mengalami kenaikan dari tahun sebelumnya. Zmijewski berada dalam kondisi yang sehat dengan hasil -0,4674 ini mengalami penurunan tetapi masih sehat karena hasil yang negative juga. Menurut Fulmer perusahaan dalam kondisi yang bangkrut karena nilai lebih kecil dari 0 dan mengalami penurunan pada variabel V1, V2, V3, V4, V6 serta V9. Grover perusahaan mengalami kondisi yang sehat karena sesuai dengan kriteria perusahaan, walaupun nilai mengalami penurunan tapi masih berada dalam kondisi yang sehat, penurunan terjadi pada variabel $X_{3}$ dan ROA. Sedangkan menurut Altman mengalami kondisi perusahaan yang bangkrut dengan nilai 0,913 , nilai ini lebih rendah dari dua tahun sebelumnya. Mengalami penurunan pada semua variabel, untuk variabel $X_{3}$ yaitu EBIT terhadap total aktiva mengalami penurunan dari setengah nya tahun sebelumnya.

Berdasarkan pembahasan analisis yang telah dilakukan bab sebelumnya maka dapat diambil kesimpulan adalah menurut Springate tahun 2013 dengan nilai 0,444, tahun 2014 dengan nilai 0,751, tahun 2015 dengan nilai 0,452 pada PT Tunas Baru Lampung mengalami kebangkrutan karena nilai perusahaan berada di bawah 0,862. Menurut Zmijewski tahun 2013 dengan nilai -0,3066, tahun 2014 dengan nilai -0,7816, tahun 2015 dengan nilai -0,4674 pada PT Tunas Baru Lampung 
mengalami kondisi perusahaan yang sehat dengan hasil nilai yang negative dan sudah memenuhi kriteria kesehatan suatu perusahaan. Menurut Fulmer pada PT Tunas Baru Lampung tahun 2013 dan tahun 2014 dengan nilai 2,463 serta 0,673 berada dalam kondisi yang sehat, tahun 2015 dengan nilai $-0,335$ berada dalam kondisi yang bangkrut.

Sementara itu menurut Grover pada PT Tunas Baru Lampung tahun 2013 dengan nilai 0,294, tahun 2014 dengan nilai 0,469 dan tahun 2015 dengan nilai 0,307 mengalami kondisi yang sehat karena sesuai dengan kriteria perusahaan yaitu 0,01. Menurut Altman Z-Score tahun 2013 dengan nilai 1,067 pada PT Tunas Baru Lampung mengalami perusahaan yang bangkrut atau tidak sehat, tahun 2014 dengan nilai 1,568 mengalami grey area atau daerah kelabu, sedangkan tahun 2015 dengan nilai 0,913 mengalami bangkrut lagi karena untuk mencapai nilai perusahaan sehat adalah 2,90. Hasil penelitian menunjukkan adanya perbedaan hasil prediksi kebangkrutan antara metode Altman Z-score, Springate, Zmijewski dan Fulmer. Hal ini dikarenakan adanya perbedaan penggunaan rasio keuangan dan kriteria kebangkrutan antara Altman Z-score, Springate, Zmijewski dan Fulmer.

\section{PENUTUP}

Menurut Springate perusahaan berada dalam kondisi bangkrut sehingga perusahaan harus bisa memperkecil atau menghilangkan hutang agar tidak ada biaya hutang. Menurut Zmijewski perusahaan dalam kondisi yang sehat tetapi perusahaan dapat memberikan strategi yang kreatif, tepat dan efektif dalam promosi agar penjualan meningkat sehingga dapat memenuhi kriteria nilai sehat perusahaan. Menurut Fulmer perusahaan dapat menekan biaya-biaya operasional agar lebih efesien, jangan sampai lebih besar dari pendapatan yang dihasilkan oleh perusahaan.

Sementara itu menurut Grover perusahaan dalam kondisi yang sehat tetapi perusahaan harus memperbaiki apabila permintaan menurun, adanya konflik karyawan, menaiknya kurs mata uang asing, dan lain lain agar perusahaan tetap dalam kondisi yang sehat. Menurut Altman Z-Score perusahaan mengalami kebangkrutan dan berada dalam grey area sehingga perusahaan perlu melakukan sosialisasi, komunikasi serta pembinaan kepada karyawan setempat yang lebih terarah, komprehensif dan tepat sasaran untuk melakukan pengembangan produk yang berupa deferensiasi dan diversifikasi produk sehingga meningkatkan nilai penjualan perusahaan.

Upaya mengantisipasi dampak pertumbuhan di China yang melambat maka perusahaan harus meningkatkan kebutuhan dan pemenuhan akan sumberdaya manusia sehingga meningkatkan nilai kebangkrutan perusahaan. Perusahaan harus bersaing untuk mendapatkan tenaga kerja professional dan terampil sehingga mendorong kemajuan perusahaan. Diharapkan pada Bursa Efek Indonesia, agar penelitian ini dapat dijadikan suatu masukan untuk pengambil keputusan perusahaan yang listing dan delisting dengan menghitung rasio keuangan dapat dimasukkan dalam model kebangkrutan untuk memprediksi perusahaan sehat atau tidak sehat.

\section{REFERENSI}

Altman, Edward I. (2000). Predicting financial distress of companies: Revisiting the z-score and zeta models. Research paper. diunduh dari http://lemeunier. gilbert.free.fr/Investissement/DOCS/ PDF/Zscores.pdf pada tanggal 30 Maret 2016.

Azwar, Saifuddin. (2012). Metode penelitian. Yogayakarta: Pustaka Pelajar.

Bursa Efek Indonesia. (2016). Laporan keuangan perusahaan. Diunduh dari www.idx.co.id. Pada tanggal 2 November 2016.

Hanafi, Mamduh \& Abdul Halim. (2014). Analisis laporan keuangan. Yogyakarta: UPP STIEM YKPN. 
Hanafi, Mamduh. (2014). Manajemen keuangan. Yogyakarta: BPFE.

Istiarti. Resty. (2014). Analisis kinerja keuangan perusahaan perkebunan kelapa sawit go public di Indonesia. Tesis. Fakultas Ekonomi dan Manajemen Institut Pertanian Bogor.

Juliana. Tri Zulhijah. (2012). Perbandingan analisis kebangkrutan pada perusahaan perkebunan yang terdaftar di bursa efek Indonesia. Tesis, Fakultas Ekonomi Universitas Mercu Buana: Yogyakarta.

Kasmir. (2010). Pengantar manajemen keuangan. Jakarta: Kencana.

Kleinert. (2014). Comparison of accounting based bankruptcy prediction models of Altman (1968), Ohlson (1980), and Zmijewski (1984) to German and Belgian listed companies during 20082013. Thesis Institution Faculty of Management and Governance. University of Twente, the Netherlands.

Martono \& Agus Harjito. (2008). Manajemen keuangan. Ekonisia Universitas Islam Indonesia

Mastuti, Saifi \& Azizah. (2013). Altman z-score sebagai salah satu metode dalam menganalisis estimasi kebangkrutan perusahaan (Studi pada perusahaan plastik dan kemasan yang terdaftar (Listing) di Bursa Efek Indonesia periode tahun 2010-2012. Tesis. Fakultas IImu Administrasi, Universitas Brawijaya: Malang.

Peter \& Yoseph. (2011). Analisis kebangkrutan dengan metode z-score altman, springate dan zmijewski pada PT. Indofood Sukses Makmur Tbk Periode 2005-2009. Akurat jurnal ilmiah akuntansi, Nomor 04 Tahun ke-2 Januari-April 2011.

Prihanthini \& Sari (2013). Prediksi kebangkrutan dengan model grover, altman z-score, springate dan zmijewski pada perusahaan food and baverage di bursa efek Indonesia. Tesis, Fakultas Ekonomi dan Bisnis, Universitas Udayana.

Rahmadini, Anissa Agustina. (2016). Analisis kesesuaian prediksi kebangkrutan model altman zscore, fulmer dan springate terhadap opini auditor pada perusahaan delisting tahun 2015. Universitas Widyatama. IKONOMIKA Jurnal ekonomi dan bisnis Islam. Volume I, Nomor 2, Oktober 2016.

Rajasekar, Ashraf, Deo. (2014). An empirical enquiry on the financial distress of navratna companies in India. Journal of accounting and finance, Vol. 14 (3) 2014.

Rasidah \& Sarwani. (2008). Analisis diskriminan model altman (Z-score) dalam mengukur kinerja keuangan untuk memprediksi kebangkrutan pada industri kayu yang terdaftar di bursa efek Jakarta. JEPMA, Vol. 7, No. 2 Agustus hal. 200-230.

Sugiyono. (2010). Metode penelitian bisnis. Bandung: CV Alfabeta.

Tunas Baru Lampung. (2016). Tentang perusahaan. Diunduh dari www.tunasbarulampung.com. Pada tanggal 2 November 2016.

Widuri. Trisnia. (2012). Analisis kinerja keuangan berdasarkan rasio profitabilitas dan z score model. Revitalisasi, Vol 1, Nomor 3, Desember 2012.

Wild, J.John \& K.R Subramanyam. (2010). Analisis laporan keuangan. Jakarta: Salemba Empat. 